\title{
Pengaruh Kinerja Keuangan terhadap Nilai Perusahaan dengan Pengungkapan Corporate Social Responsibility Sebagai Variabel Pemoderasi
}

\author{
Gine Das Prena dan I Gede Iwan Muliyawan \\ Fakultas Ekonomi, Universitas Pendidikan Nasional, Denpasar, Bali-Indonesia
}

ginedasfrena@undiknas.ac.id

How to cite (in APA style):

Prena, G. D., \& Muliyawan, I. G. I. (2020). Pengaruh Kinerja Keuangan terhadap Nilai Perusahaan dengan Pengungkapan Corporate Social Responsibility Sebagai Variabel Pemoderasi. Wacana Ekonomi (Jurnal Ekonomi, Bisnis dan Akuntansi). 19(2), pp.131-142. https://doi.org/10.22225/we.19.2.1955.131-142

\begin{abstract}
The study was conducted to examine the effect of financial performance proxied by ROA on company value proxied by Tobin's $Q$ and test whether Corporate Social Responsibility (CSR) able to moderate the relationship between financial performance and company value. Data collection of this study was from publications published of Indonesia Stock Exchange (IDX). The population in this study are Manufacturing companies that listed on the Indonesian Stock Exchange in 2017. The samples in this study are Manufacturing companies according to the criteria set. The data analysis technique used in this study are simple linear regression and moderation regression to determine the dependent variable influenced by independent variables and hypothesis testing using t-statistics to test the partial regression coefficient. Besides that, classic assumption test was also conducted which included test of normality, heteroscedasticity test and multicollinearity test. During the observation period, the research data were normally distributed. Based on the normality test, heteroscedasticity test and multicollinearity test found no deviating variables from the classical assumption test. This shows the available data has met the requirements using a simple regression equation model and moderation regression. The results of this study indicate that financial performance has a positive and significant effect by firm value, meaning that the high and low ratio of net income to total assets has implications for the high and low value of company. Likewise, CSR that able to moderate the financial performance of the company value, meaning that CSR disclosure can strengthen a relationship of the financial performance that has implications for increasing a value of the company.
\end{abstract}

Keywords: ROA; Tobins Q; CSR disclosure

\begin{abstract}
Abstrak
Penelitian dilakukan untuk menguji pengaruh kinerja keuangan yang diproksikan dengan ROA terhadap nilai perusahaan yang diproksikan dengan Tobin's Q dan menguji apakah Corporate Social Responsibility (CSR) mampu memoderasi hubungan antara kinerja keuangan dan nilai perusahaan. Pengumpulan data penelitian ini berasal dari publikasi yang diterbitkan di Bursa Efek Indonesia (BEI). Populasi dalam penelitian ini adalah perusahaan Manufaktur yang terdaftar di Bursa Efek Indonesia tahun 2017. Sampel dalam penelitian ini adalah perusahaan Manufaktur sesuai kriteria yang ditetapkan. Teknik analisis data yang digunakan dalam penelitian ini adalah regresi linier sederhana dan regresi moderasi untuk mengetahui variabel dependen yang dipengaruhi oleh variabel independen dan pengujian hipotesis menggunakan statistik-t untuk menguji koefisien regresi parsial. Selain itu juga dilakukan uji asumsi klasik yang meliputi uji normalitas, uji heteroskedastisitas dan uji multikolinieritas. Selama periode observasi, data penelitian berdistribusi normal. Berdasarkan uji normalitas, uji heteroskedastisitas dan uji multikolinieritas tidak ditemukan variabel yang menyimpang dari uji asumsi klasik. Hal ini menunjukkan data yang tersedia telah memenuhi persyaratan dengan menggunakan model persamaan regresi sederhana dan regresi moderasi. Hasil penelitian ini menunjukkan bahwa kinerja keuangan berpengaruh positif dan signifikan terhadap nilai perusahaan, artinya tinggi rendahnya rasio laba bersih terhadap total aset berimplikasi pada tinggi rendahnya nilai perusahaan. Begitu pula CSR yang mampu memoderasi kinerja keuangan terhadap nilai perusahaan, artinya pengungkapan CSR dapat memperkuat hubungan kinerja keuangan yang berimplikasi pada peningkatan nilai perusahaan.
\end{abstract}

Kata Kunci: ROA; Tobins; Pengungkapan CSR

\section{PENDAHULUAN}

Nilai Perusahaan merupakan tujuan utama didirikannya suatu perusahaan (Rahayu, 2010). 
Semakin tinggi nilai perusahaan maka investor atau pemegang saham tidak akan ragu menanamkan modalnya. Salah satu pengaruh naik turunnya nilai perusahaan adalah kinerja keuangan, terutama kemampuan perusahaan dalam menghasilkan keuntungan atau laba.

Analisis rasio keuangan merupakan salah satu cara yang dapat digunakan untuk menilai kinerja keuangan perusahaan. Dalam penelitian ini, rasio keuangan yang digunakan untuk mengukur kinerja keuangan adalah Return On Asset (ROA). ROA merupakan salah satu wujud dari rasio profitablitas, yang dimana dalam penggunaannya digunakan untuk mengukur kemampuan perusahaan dalam menghasilkan keuntungan atau laba. Pada Penelitian (Yuniasih \& Wirakusuma, 2009) membuktikan Return On Asset (ROA) berpengaruh positif terhadap nilai perusahaan, dengan menggunakan CSR sebagai variabel moderasi yang berpengaruh positif dalam memoderasi hubungan kinerja keuangan dengan nilai perusahaan.

CSR merupakan bentuk tanggung jawab perusahaan dalam menangani kerusakan lingkunagan yang terjadi akibat operasional perusahaan serta memperbaiki kesenjangan social yang terjadi di lingkungan perusahaan berdiri (Retno \& Priantinah, 2012). Jika perusahaan melakukan pertanggungjawaban yang tinggi terhadap lingkungannya, image/nilai perusahaan akan meningkat. Investor lebih tertarik menanamkan modalnya jika perusahaan dipandang memiliki citra yang bagus dimata masyarakat, karena semakin bagusnya citra perusahaan, loyalitas dan kesetiaan konsumen akan semakin tinggi, sehingga akan berdampak pada keuntungan perusahaan yang semakin meningkat. Menurut (Retno \& Priantinah, 2012) pengungkapan CSR menunjukkan pengaruh yang positif terhadap hubungan kinerja keuangan dan nilai perusahaan Namun hasil yang berbeda ditemukan pada penelitian (Oktaviani, 2013) yang menyatakan variabel moderasi CSR tidak mampu memoderasi hubungan antara ROA terhadap nilai perusahaan.

Berdasarkan pendahuluan dan beberapa referensi dari penelitian diatas, Penelitian dilakukan untuk menguji pengaruh kinerja keuangan yang diproksikan dengan ROA terhadap nilai perusahaan yang diproksikan dengan Tobin's Q dan menguji apakah Corporate Social Responsibility (CSR) mampu memoderasi hubungan antara kinerja keuangan dan nilai perusahaan. Pengumpulan data penelitian ini berasal dari publikasi yang diterbitkan di Bursa Efek Indonesia (BEI).

\section{KAJIAN LITERATUR}

\section{Teori Steakholder}

Stakeholder theory adalah kumpulan kebijakan dan praktik yang berhubungan dengan stakeholder, nilai-nilai, pemenuhan ketentuan hukum, penghargaan masyarakat dan lingkungan, serta komitmen dunia usaha untuk berkontribusi dalam pembangunan secara berkelanjutan (Hadianto, 2013). Perusahaan tidak hanya beroperasi untuk kepentingannya sendiri, namun harus memberikan manfaat bagi stakeholders-nya (pemegang saham, kreditor, konsumen, supplier, pemerintah, masyarakat, analis dan pihak lain).

\section{Teori Sinyal}

Teori sinyal membahas mengenai dorongan perusahaan untuk memberikan informasi kepada pihak eksternal. Dorongan tersebut disebabkan karena terjadinya asimetri informasi antara pihak manajemen dan pihak eksternal. Perusahaan harus mengungkapkan informasi yang dimiliki baik informasi untuk keuangan ataupun informasi non keuangan, sehingga dapat mengurangi asimetri informasi (Rustiarini, 2010).

\section{Kinerja Keuangan}

Laporan keuangan merupakan suatu ringkasan transaksi-transaksi keuangan yang terja di selama tahun buku yang bersangkutan (Baridwan, 2000). Agar terpenuhinya kebutuhan pemangku kepentingan, maka perusahaan harus menerbitkan laporan keuangan paling lambat satu tahun buku. Laporan keuangan yang lengkap biasanya menunjukkan laporan posisi keuangan, laporan laba rugi, laporan perubahan ekuitas, laporan arus kas, serta catatan atas laporan keuangan. Dalam penelitian ini, rasio keuangan yang dipilih untuk memproyeksikan kinerja keuangan adalah Return On Asset (ROA).

\section{Nilai Perusahaan}


Nilai perusahaan sangat penting karena nilai perusahaan merupakan nilai jual yang tercermin dari harga pasar sahamnya. Dalam melihat tingginya nilai perusahaan, dapat dilihat dari tingginya nilai saham yang dimiliki pemegang saham atas investasinya. Untuk mengukur nilai perusahaan dapat dilakukan dengan (Weston \& Copeland, 1995):

- Price Earning Ratio (PER)

- Price to Book Value (PBV)

- Tobin's $Q$ Tobin's Q.

Dalam penelitian ini, penulis lebih menekankan nilai perusahaan dengan menggunakan metode

\section{Corporate Social Responsibility (CSR)}

Definisi umum menurut (World Business Council Suistanable Development dan (PSAK), 1998) adalah sebuah komitmen perusahaan untuk berperilaku etis serta berkontribusi terhadap pembangunan ekonomi yang berkelanjutan dengan meningkatkan kualitas hidup karyawan, keluarganya, komunitas lokal dan masyarakat luas. Ruang lingkup Corporate Sosial Responsibility perusahaan merupakan pengklasifikasian dari bidang - bidang utama perusa haan perseroan atas perbuatan sosial untuk memudahkan perusahaan dalam mengetahui item - item mana saja yang merupakan tanggungjawab sosialnya.

Pengungkapan CSR merupakan bagian akuntansi pertanggungjawaban sosial kepada stakeholder. Perusahaan yang telah melaksanakan praktik CSR dapat mengungkapkan pelaksanaan CSR tersebut baik terintegrasi langsung dalam laporan tahunan maupun laporan terpisah yang disebut dengan sustainability report (Annisa \& Nazar, 2015). Di Indonesia, standar pengungkapan CSR merujuk pada standar yang diterapkan GRI (Global Reporting Initiative). Dipilihnya standar GRI karena lebih fokus dalam standar pengungkapan sebagai kinerja ekonomi, sosial dan lingkungan perusahaan dengan tujuan untuk meningkatkan kualitas dan pemanfaatan sustainability reporting (www.globalreporting.org).

\section{Perumusan Hipotesis}

H1: Kinerja keuangan berpengaruh terhadap nilai perusahaan.

H2: Pengungkapan CSR mempengaruhi hubungan kinerja keuangan dengan nilai perusahaan.

\section{Definisi Operaional Variabel}

\section{Variabel Dependent}

Variabel dependen atau variabel terikat (Y) merupakan variabel yang nilainya tergantung dari nilai variabel lain, dan variabel $Y$ dalam penelitian ini yaitu nilai perusahaan. Dalam penelitian ini, alat yang digunakan untuk mengukur nilai perusahaanadalah Tobin's Q. rumus perhitungannya adalah sebagai berikut:

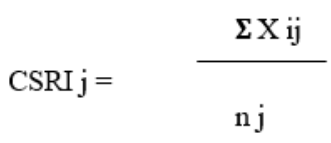

Dimana:

Q : nilai perusahaan

EMV : nilai pasar ekuitas (EMV = closing price $\mathrm{x}$ jumlah saham)

D : nilai buku dari total hutang

EBV : nilai buku dari total aktiva

Cara menghitung EMV adalah dengan mengalikan harga saham penutupan (closing price) akhir tahun dengan jumlah saham yang beredar pada akhir tahun.

\section{Variabel Independen}

Variabel independent atau variabel bebas $(\mathrm{X})$ adalah variabel yang yang memiliki pengaruh atau yang menjadi sebab perubahannya variabel dependen. Dalam penelitian ini, alat yang digunakan untuk mengukur kinerja keuangan dalah ROA. Rumus yang digunakan untuk menghitung ROA adalah sebagai berikut: 


$$
\text { ROA }=\frac{\text { Laba Bersih Setelah Pajak }}{\text { Nilai Total Aktiva }} \times 100 \%
$$

Variabel Pemoderasi

Variabel moderasi (Zi) dalam penelitian ini adalah Corporate Social Responsibility (CSR). Standar yang dipakai untuk mengungkapkan CSR adalah GRI G-4. Dalam standar GRI G-4, indikator kinerja dibagi menjadi tiga komponen utama, yaitu ekonomi, lingkungan hidup dan sosial. Kategori sosial mencakup hak asasi manusia, praktek ketenagakerjaan dan lingkungan kerja, tanggung jawab produk dan masyarakat. Total indikator yang terdapat dalam GRI mencapai 91 item (www.globalreporting.org).

Perhitungan indeks dilakukan dengan Rumus perhitungan CSRI sebagai berikut:

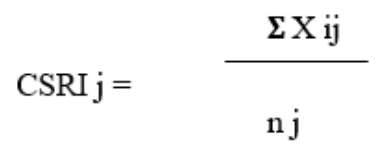

Dimana :

CSRI j : Corporate Social Responsibility Disclosure Index perusahaan j

$\mathrm{n} \mathrm{j} \quad$ : Jumlah item untuk perusahaan $\mathrm{j}, \mathrm{nj}=91$ (Skor maksimal)

$\boldsymbol{\Sigma} \mathrm{X}$ ij $\quad$ Jumlah total pengungkapan CSR oleh perusahaan. $1=$ jika item diungkapkan; $0=$ jika item tidak diungkapkan.

\section{METODE}

Penelitian ini dilakukan pada perusahaan manufaktur yang terdaftar di Bursa Efek Indonesia (BEI) tahun 2017. Alasan dipilihnya BEI karena merupakan sarana Pasar Modal terbesar di Indonesia sehingga mudah diperoleh informasi yang menunjang penelitian. Populasi penelitian ini adalah perusahaan yang tergolong dalam sektor industri manufaktur yang terdaftar di Bursa Efek Indonesia (BEI) tahun 2017. Adapun jumlah perusahaan sector manufaktur yang terdaftar di BEI tahun 2017 sebanyak 152 perusahaan. Dipilihnya satu sektor industri yaitu industri manufaktur sebagai populasi karena sektor manufaktur memiliki jumlah terbesar perusahaan dibandingkan sektor lainnya. Sehingga penulis lebih mudah memperoleh informasi yang menunjang penelitian. Metode yang digunakan dalam pemilihan sampel dalam penelitian ini menggunakan metode purposive sampling yakni pengambilan sampel dari populasi berdasarkan suatu kriteria tertentu. Adapun kriteria purposive sampling dalam penelitian ini adalah sebagai berikut:

- Perusahaan manufaktur yang terdaftar di BEI pada tahun 2017 yang menerbitkan laporan tahunan (annual report);

- Perusahaan manufaktur yang mempublikasikan laporan keuangan yang berakhir 31 Desember dan menggunakan mata uang Rupiah;

- Data mengenai variabel-variabel yang diteliti tersedia secara lengkap serta memenuhi kriteria dalam laporan keuangan perusahaan selama tahun 2017.

Tahapan penentuan sampel pada perusahaan manufaktur yang terdaftar di Brusa Efek Indonesia (BEI) berdasarkan kriteria yang sudah ditentukan, dapat dilihat pada tabel berikut: 
Wacana Ekonomi (Jurnal Ekonomi Bisnis dan Akuntansi), 19 (2) 2020, 135

Tabel 1

Tahap Penentuan Jumlah Sampel

\begin{tabular}{ccc}
\hline No. & Kriteria Pengambilan Sampel & Jumlah \\
\hline 1 & Perusahaan manufaktur yang terdaftar di Brusa Efek & 152 \\
Indonesia (BEI ) tahun 2017 & (14) \\
2 & $\begin{array}{c}\text { Perusahaan manufaktur yang tidak mempublikasikan laporan } \\
\text { keuangan yang berakhir 31 Desember 2017 } \\
\text { Perusahaan manufaktur yang tidak menyampaikan data } \\
\text { mengenai variabel-variabel yang diteliti tersedia secara } \\
\text { lengkap serta memenuhi kriteria dalam laporan keuangan } \\
\text { perusahaan selama tahun 2017 }\end{array}$ & (121) \\
& Jumlah Sampel Perusahaan yang Memenuhi Kriteria & $\mathbf{1 7}$ \\
\hline
\end{tabular}

Jenis data yang digunakan dalam penelitian ini adalah data kuantitatif . Data kuantitatif adalah data yang berbentuk angka atau data kuantitatif (Sugiyono, 2014). Data kuantitatif dalam penelitian ini adalah laporan keuangan atau laporan tahunan (annual report) masing-masing perusahaan manufaktur yang terdaftar di Bursa Efek Indonesia periode tahun 2017. Data yang digunakan dalam penelitian ini mengunakan data sekunder. Data sekunder penelitian ini berupa data laporan keuangan dan laporan tahunan perusahaan manufaktur yang terdaftar di Bursa Efek Indonesia yang diperoleh dari situs BEI yaitu www.idx.co.id. Selain itu, diperoleh dari halaman web yang berkaitan, laporan penelitian sebelumnya, dan jurnal yang berkaitan dengan masalah peran Corperate Social Responsibility sebagai pemoderasi dari hubungan kinerja keuangan terhadap nilai perusahaan. Data diperoleh dengan menggunakan metode dokumentasi yaitu penelitian yang dilakukan dengan mengumpulkan data-data tertulis yang ada kaitannya dengan penelitian ini. Data berupa laporan keuangan yang diterbitkan oleh perusahaan manufaktur yang terdaftar di Bursa Efek Indonesia yang telah diaudit tahun 2017.

\section{Teknik Analisis Data}

Teknik analisis data pada penelitian ini dilakukan untuk menguji apakah kinera keuangan berpengaruh terhadap nilai perusahaan, serta untuk menguji apakah Corporate Social Responsibility (CSR) berpengaruh terhadap hubungan kinerja keuangan dengan nilai perusahaan. Prosedur analisis yang digunakan dalam penelitian ini adalah sebagai berikut:

\section{Analisis Statistik Deskriptif}

Statistic descriptivef adalah suatu alat analisis data yang dapat memberikan informasi berupa nilai rata-rata (mean), standar deviasi, varian, maksimum, minimum, sum, range, kurtosis, dan skewness (Ghozali, 2005).

\section{Uji Asumsi Klasik}

Suatu model regresi yang digunakan untuk menguji hipotess harus memenuhi asumsi klasik agar model regresi menjadi suatu model yang lebih representatif. Uji asumsi klasik yang dilakukan dalam penelitian ini adalah: uji normalitas, uji multikolonieritas, uji heteroskedastisitas.

\section{Pengujian Hipotesis}

Uji hipotesis ini digunakan untuk melihat apakah variabel independen yaitu kinerja keuangan, variabel pemoderasi yaitu Corporate Social Responsibility berpengaruh atau tidak terhadap nilai perusahaan. Uji hipotesis ini meliputi:

\section{Analisis Regresi Linier Sederhana}

Alat analisis yang digunakan untuk menguji hipotesis 1 adalah regresi linier sederhana. Analisis ini merupakan suatu analisis yang digunakan untuk mengetahui apakah variabel independen (X) mempunyai hubungan dengan variabel dependen (Y). Penelitian ini menggunakan analisis regresi linier sederhana karena hanya menggunakan satu variabel independen. Persamaan regresinya sebagai berikut:

$$
\begin{aligned}
& \mathrm{Q}=\mathrm{a}+\mathrm{b} 1 \mathrm{ROA}+\mathrm{e} \\
& \text { Keterangan: } \quad=\text { Nilai perusahaan yang diukur dengan Tobins } \mathrm{Q} \text { periode } \mathrm{t} . \\
& \mathrm{Q}
\end{aligned}
$$




$\begin{array}{ll}\text { ROA } & =\text { Kinerja keuangan yang diukur dengan ROA periode } \mathrm{t} . \\ \mathrm{e} & =\text { error term. }\end{array}$

Uji Interaksi atau Moderated Regression Analysis (MRA)

Moderated regression analysis (MRA) digunakan untuk menguji hipotesis 2. MRA adalah analisis regresi yang menggunakan pendekatan analitik yang mempertahankan integritas sampel dan memberikan dasar untuk mengontrol pengaruh variabel moderator. Tujuan analisis ini adalah menguji variabel moderating CSR, apakah memperkuat atau justru memperlemah hubungan variabel independent $(\mathrm{X})$ dengan variabel dependen $(\mathrm{Y})$. Variabel moderasi dapat dikatakan sebagai pure moderator jika interaksi antara variabel moderasi dan variabel independen berpengaruh signifikan terhadap variabel dependen (Fachrurrozie \& Utaminingsih, 2014). Persamaan regresinya sebagai berikut:

$$
\begin{aligned}
& \text { Hipotesis2: } \mathrm{Q}=\mathrm{a}+\mathrm{b} 1 \mathrm{ROA}+\mathrm{b} 2 \mathrm{CSR}+\mathrm{b} 4 \mathrm{ROA} * \mathrm{CSR}+\mathrm{e} \\
& \text { Keterangan: } \\
& \begin{array}{ll}
\mathrm{Q}=\text { Nilai perusahaan yang diukur dengan Tobins } \mathrm{Q} \text { periode } \mathrm{t} . \\
\mathrm{ROA} \quad=\text { Kinerja keuangan yang diukur dengan ROA periode } \mathrm{t} \text {. } \\
\mathrm{CSR} \quad=\text { Tanggung jawab sosial perusahaan diukur dengan CSR periode } \mathrm{t} . \\
\mathrm{e} \quad=\text { Error term. }
\end{array}
\end{aligned}
$$

\section{Uji Koefisien Determinasi R2}

Koefisien determinasi adalah ikhtisar yang menyatakan seberapa bagus garis regresi dalam mencocokkan data (Ghozali, 2007). Nilai $\mathrm{R}^{2}$ dinyatakan dalam angka yang memliki kisaran 0-1. Hasil R2 yang rendah artinya lemahnya kemampuan variabel independent dalam menjelaskan variasi variabel dependen. Sebaliknya, jika nilai $\mathrm{R}^{2}$ yang dihasilkan tinggi (mendekati 1) maka dapat diartikan variabel independen memberikan hampir semua informasi yang dibutuhkan untuk memprediksi variasi variabel dependen.

\section{Uji Signifikansi Parsial (Uji t)}

Uji t digunakan untuk menguji variabel-variabel independen secara individu berpengaruh dominan dengan taraf signifikansi 5\%. Apabila tingkat signifikansi yang diperoleh (sig $t$ ) lebih besar dari 0,05 maka $\mathrm{H}_{\mathrm{a}}$ ditolak sedangkan jika tingkat signifikansi yang diperoleh labih kecil dari 0,05 maka $\mathrm{H}_{\mathrm{a}}$ diterima.

\section{HASIL DAN PEMBAHASAN}

\section{Analisis Statistik Deskriptif}

Statistik deskriptif dalam penelitian ini digunakan untuk memberikan informasi mengenai vaiabel-variabel penelitian yaitu kinerja keuangan, Corporate Social Responsibility dan nilai perusahaan. Data yang dilihat adalah jumlah data, nilai minimum, nilai maksimum, nilai rata-rata dan standar deviasi (Ghozali, 2005). Adapun nilai deskriptif variabel penelitian disajikan dalam tabel berikut:

Tabel 2

Hasil Analisis Statistik Deskriptif Descriptive Statistics

\begin{tabular}{cccccc}
\hline & $\mathrm{N}$ & Minimum & Maximum & Mean & Std. Deviation \\
\hline Tobin's Q & 17 & -5.99 & 37.05 & 8.1029 & 10.63796 \\
ROA & 17 & .31 & 22.55 & 3.3847 & 5.77443 \\
CSR & 17 & .15 & .55 & .3953 & .10701 \\
Valid N (listwise) & 17 & & & & \\
\hline
\end{tabular}

Sumber: Hasil Olah Data IMB SPSS Statistics 23

\section{Uji Asumsi Klasik}

Uji Normalitas

Uji statistik yang digunakan untuk uji normalitas data dalam penelitian ini adalah uji 
normalitas atau sampel kolmogorov-Smirnov. Hasil uji normalitas menunjukkan nilai sebagai berikut:

Tabel 3

Hasil Uji Normalitas

One-Sample Kolmogorov-Smirnov Test

\begin{tabular}{|c|c|c|}
\hline \multicolumn{2}{|l|}{$\mathrm{N}$} & $\begin{array}{c}\text { Unstandardized } \\
\text { Residual } \\
17\end{array}$ \\
\hline \multirow{2}{*}{ Normal Parameters ${ }^{\mathrm{a}, \mathrm{b}}$} & Mean & .0000000 \\
\hline & Std. Deviation & 2.02734017 \\
\hline \multirow{3}{*}{ Most Extreme Differences } & Absolute & .154 \\
\hline & Positive & .154 \\
\hline & Negative & -.119 \\
\hline \multicolumn{2}{|c|}{ Test Statistic } & .154 \\
\hline \multicolumn{2}{|c|}{ Asymp. Sig. (2-tailed) } & $.200^{\mathrm{c}, \mathrm{d}}$ \\
\hline
\end{tabular}

Test distribution is Normal.

Sumber: Hasil Olah Data IMB SPSS Statistics 23

Berdasarkan hasil di atas, diketahui nilai signifikansi sebesar 0,200 $>0.05$, sehingga dapat disimpulkan bahwa data yang diuji berdistribusi normal atau dalam model regresi, variabel pengganggu atau residual berdistribusi normal.

\section{Uji Multikolonieritas}

Uji multikolinearitas bertujuan untuk menguji apakah model regresi ditemukan adanya korelasi antar variabel bebas atau independen (Ghozali, 2005). Cara untuk menguji adanya multikolinearitas dapat dilakukan dengan melakukan analisis korelasi antara variabel dan perhitungan nilai tolerance serta variance inflation factor (VIF). Dikatakan tidak terjadi gejala multikolonieritas jika nilai VIF kurang dari 10 dan nilai tolerance lebih dari 0,1.

\section{Tabel 4}

Hasil Uji Multikolobieritas

Tabel Coefficients ${ }^{\mathrm{a}}$

\begin{tabular}{ccccccccc}
\hline \multirow{2}{*}{ Model } & \multicolumn{2}{c}{$\begin{array}{c}\text { Unstandardized } \\
\text { Coefficients }\end{array}$} & \multicolumn{2}{c}{$\begin{array}{c}\text { Standardized } \\
\text { Coefficients }\end{array}$} & $\mathrm{t}$ & Sig. & \multicolumn{2}{c}{ Collinearity Statistics } \\
& & $\mathrm{B}$ & Std. Error & Beta & & & Tolerance & VIF \\
\hline \multirow{4}{*}{1} & (Constant) & -1.753 & 2.076 & & -.844 & .413 & & \\
& ROA & .500 & .053 & .920 & 9.391 & .000 & .917 & 1.091 \\
& CSR & 2.758 & 5.288 & .051 & .521 & .610 & .917 & 1.091 \\
\hline
\end{tabular}

Dependent Variable: Tibins q

Sumber: Hasil Olah Data IMB SPSS Statistics 23

Berdasarkan table hasil uji olah data diatas, dapat dilihat bahwa nilai tolerancenya $0,917>0,1$ dan nilai variance inflation factor (VIF) $1,091<10$. Maka dapat disimpulkan bahwa korelasi antar variabel bebas atau independent tidak terjadi multikolonieritas.

\section{Uji Heteroskedastisitas}

Uji heteroskedastisitas dilakukan untuk menguji apakah data memiliki varian yang sama atau tidak. Dalam penelitian ini dilakukan dengan Uji Glejser. Hasil uji heteroskedastisitas dapat dilihat pada tabel berikut: 
Wacana Ekonomi (Jurnal Ekonomi Bisnis dan Akuntansi), 19 (2) 2020, 138

Tabel 5

Hasil Uji Heteroskedastisitas

Coefficients $^{\mathrm{a}}$

\begin{tabular}{ccccccc}
\hline \multicolumn{2}{c}{ Model } & \multicolumn{2}{c}{ Unstandardized Coefficients } & $\begin{array}{c}\text { Standardized } \\
\text { Coefficients } \\
\text { Beta }\end{array}$ & $\mathrm{t}$ & Sig. \\
\hline \multirow{2}{*}{1} & (Constant) & 1.362 & 1.166 & & 1.168 & .262 \\
& ROA & .040 & .030 & .352 & 1.343 & .201 \\
& CSR & -.282 & 2.970 & -.025 & -.095 & .926 \\
\hline
\end{tabular}

Dependent Variable: RES2

Sumber: Hasil Olah Data IMB SPSS Statistics 23

Berdasarkan tabel 5 dapat dilihat bahwa masing-masing variabel independen dalam penelitian ini (ROA, CSR) memiliki nilai signifikansi lebih besar dari 0,05. Berdasarkan hasil tersebut maka dapat disimpulkan bahwa pada model regresi tidak terjadi gejala heteroskedastisitas.

\section{Pengujian Hipotesis 1 (H1)}

\section{Uji Koefisien Determinasi R2}

Koefisien determinasi model pertama digunakan untuk mengetahui seberapa besar kemampuan variabel independen dalam menjelaskan variasi variabel dependen. Hasil analisisnya dijelaskan dalam tabel berikut:

Tabel 6

Hasil uji Koefisien Regresi $\mathrm{R}^{2}$ Regresi Sederhana

Model Summary

\begin{tabular}{ccccc}
\hline Model & $\mathrm{R}$ & $\mathrm{R}$ Square & Adjusted R Square & Std. Error of the Estimate \\
\hline 1 & $.935^{\mathrm{a}}$ & .874 & .866 & 2.11407 \\
\hline
\end{tabular}

Predictors: (Constant), ROA

Sumber: Hasil Olah Data IMB SPSS Statistics 23

Berdasarkan hasil diatas, diketahui bahwa nilai adjusted R2 adalah 0,866 yang menunjukkan bahwa $86,6 \%$ variasi perubahan nilai perusahaan dijelaskan oleh kinerja keuangan, sedangkan $13,4 \%$ variasi lainnya dijelaskan oleh variabel lain selain variabel tersebut.

\section{Uji Signifikansi Parsial (Uji t)}

Analisis regresi sederhana digunakan untuk menguji pengaruh kinerja keuangan yang diproksi oleh ROA terhadap nilai perusahaan yang diproksi oleh Tobin's Q. Hasil analisis regresi sederhana sebagai ditampilkan pada table 7 berikut:

Tabel 7

Hasil Analisis Regresi Linier Sederhana

Coefficients $^{\mathrm{a}}$

\begin{tabular}{|c|c|c|c|c|c|c|}
\hline & \multirow{2}{*}{ Model } & \multicolumn{2}{|c|}{ Unstandardized Coefficients } & \multirow{2}{*}{$\begin{array}{c}\text { Standardized } \\
\text { Coefficients } \\
\text { Beta }\end{array}$} & \multirow{2}{*}{$\mathrm{t}$} & \multirow{2}{*}{ Sig. } \\
\hline & & B & Std. Error & & & \\
\hline \multirow{2}{*}{1} & (Constant) & -.728 & .652 & & -1.117 & .282 \\
\hline & $\mathrm{ROA}$ & .508 & .050 & .935 & 10.216 & .000 \\
\hline
\end{tabular}

Dependent Variable: Tobin's q

Sumber: Hasil Olah Data IMB SPSS Statistics 23

Berdasarkan pengolahan data SPSS dihasilkan persamaan regresi linier sebagai berikut: $Q=a$ + b1ROA + e, yang menunjukkan nilai koefisien regresi yang positif sebesar 0,508 , hal ini berarti Return On Assets memiliki pengaruh yang positif terhadap Nilai Perusahaan, atau dengan kata lain 
semakin besar Return On Assets maka semakin meningkatkan nilai perusahaan. Hasil ini diperkuat oleh hasil uji t yang menunjukkan nilai angka signifikansi sebesar 0,000 (lebih kecil dari 0,05) menjelaskan bahwa Return On Assets memiliki pengaruh yang signifikan (nyata) terhadap Nilai Perusahaan. Dengan demikian H01 ditolak dan hipotesis 1 (Ha1) yang berbunyi "kinerja keuangan (ROA) berpengaruh terhadap nilai perusahaan" diterima.

\section{Pengujian Hipotresis 2 (H2)}

\section{Uji Koefisien Determinasi R2}

Pada uji koefisien determinasi model kedua ditambahkan variabel moderasi CSR untuk mengetahui apakah variabel CSR mampu memperkuat atau memperlemah pengaruh hubungan kinerja keuangan dengan nilai perusahaan. Hasil analisisnya ditampilkan dalam tabel berikut:

Tabel 8

Hasil Uji Koefisien Determinasi $\mathrm{R}^{2}$ Regresi Moderasi MRA

Model Summary

\begin{tabular}{ccccc}
\hline Model & R & R Square & Adjusted R Square & Std. Error of the Estimate \\
\hline 1 & $.977^{\mathrm{a}}$ & .954 & .943 & 1.38014 \\
\hline
\end{tabular}

Predictors: (Constant), ROA*CSR, CSR, ROA

Sumber: Hasil Olah Data IMB SPSS Statistics 23

Pada koefisien determinasi MRA di atas diperoleh nilai adjusted R2 sebesar 0,934. Hal ini berarti $93,4 \%$ variasi perubahan nilai perusahaan mampu dijelaskan dengan baik oleh CSR, kinerja keuangan, dan moderasi. Sedangkan $6,6 \%$ variasi lainnya dijelaskan oleh variabel lain selain variabel tersebut.

Dari hasil adjusted R2 pada dua Model di atas, maka dilakukan perbandingan nilai koefisien determinasi. Berdasarkan hasil uji model 1 adalah sebesar 0,866 atau sebesar 86,6\%, sedangkan setelah adanya variabel moderating CSR nilai adjusted R2 model 2 meningkat menjadi 0,943 atau $94,3 \%$. Hal ini mengindikasikan bahwa model yang memasukkan variabel moderasi memiliki daya jelas yang lebih tinggi terhadap variasi perubahan nilai perusahaan, dengan demikian dapat disimpulkan bahwa CSR mampu memperkuat atau meningkatkan pengaruh kinerja keuangan terhadap nilai perusahaan.

\section{Uji Signifikansi Parsial (Uji t)}

Uji Interaksi atau MRA dimaksudkan untuk menguji pengaruh moderasi yaitu dengan model regresi moderasi dari variable independen. Dalam uji MRA terdapat kombinasi antara ROA (X) dan CSR (Zi) dan berpengaruh terhadap Tobin's Q (Y). Kombinasi ini diharapkan akan berpengaruh terhadap nilai perusahaan. Rumus regresi untuk menguji hipotesis 2 adalah:

\begin{tabular}{|c|c|c|c|c|c|c|}
\hline \multicolumn{7}{|c|}{$\begin{array}{c}\text { Hasil Uji Interaksi atau Moderated Regression Analysis (MRA) } \\
\text { Coefficients }^{\mathrm{a}}\end{array}$} \\
\hline & \multirow{2}{*}{ Model } & \multicolumn{2}{|c|}{ Unstandardized Coefficients } & \multirow{2}{*}{$\begin{array}{c}\text { Standardized } \\
\text { Coefficients } \\
\text { Beta }\end{array}$} & \multirow{2}{*}{$\mathrm{t}$} & \multirow{2}{*}{ Sig. } \\
\hline & & B & Std. Error & & & \\
\hline \multirow{4}{*}{1} & (Constant) & 2.799 & 1.647 & & 1.700 & .113 \\
\hline & ROA & -.782 & .278 & -1.440 & -2.809 & .015 \\
\hline & CSR & -7.010 & 3.971 & -.130 & -1.765 & .101 \\
\hline & $\mathrm{ROA}^{*} \mathrm{CSR}$ & 2.759 & .595 & 2.434 & 4.639 & .000 \\
\hline
\end{tabular}

Dependent Variable: Tobin's q

Sumber: Hasil Olah Data IMB SPSS Statistics 23

Hasil pengolahan data SPSS pada Tabel 9 menunjukkan bahwa variable moderating CSR ternyata signifikan dengan nilai koefisien regresi (standardized coefficients) sebesar 2,795 dan angka 
signifikansi sebesar 0,000 (lebih kecil dari 0,05). Hal ini berarti bahwa variabel CSR merupakan variabel moderating yang memoderasi pengaruh Return On Assets terhadap nilai perusahaan. Dapat disimpulkan bahwa H02 ditolak dan hipotesis 2 (Ha2) yang berbunyi "pengungkapan CSR berpengaruh terhadap hubungan kinerja keuangan (ROA) dengan nilai perusahaan", diterima.

\section{Pembahasan Hasil Penelitian}

Dalam penelitian ini menguji pengaruh kinerja keuangan perusahaan (ROA) terhadap nilai perusahaan (Tobin's Q) dengan Corporate Social Responsibility (CSR) sebagai variabel pemoderasi. Sebagaimana yang telah dipaparkan diatas, terdapat tiga pengujian hipotesis dalam penelitian ini. Hipotesis pertama yang menguji pengaruh ROA terhadap Tobin's Q diterima, dan hipotesis keduayang menguji pengaruh pengungkapan Corporate Social Responsibility (CSR) mmapu memoderasi hubungan antara kinerja keuangan dengan nilai perusahaan.

\section{Pengaruh Kinerja Keuangan terhadap Nilai Perusahaan}

Hipotesis 1 membuktikan bahwa kinerja keuangan yang diproksi oleh ROA berpengaruh signifikan terhadap nilai perusahaan. Berdasarkan tabel 7 diketahui bahwa variabel ROA berpengaruh positif dan signifikan terhadap Tobin's Q, dengan nilai koefisisen regresi positif sebesar 0,508 dengan nilai signifkan sebesar $0,000<0,05$, artinya kinerja keuangan berbanding lurus dengan nilai perusahaan. Hasil penelitian ini mendukung dan sejalan dengan penelitian (Heriani, 2017; Yuniasih \& Wirakusuma, 2009) yang memeroleh hasil bahwa kinerja keuangan berpengaruh positif terhadap nilai perusahaan. Hal ini mengindikasikan bahwa semakin tinggi kinerja keuangan (ROA) pada perusahaan manufaktur menunjukkan semakin besar kepercayaan dari pihak luar, sehingga sangat memungkinkan meningkatkan nilai perusahaan.

Berdasarkan Teori Sinyal, bahwa profitabilitas yang dimiliki oleh suatu perusahaan ini dapat menjadi sinyal yang positif bagi investor. Dalam profitabilitas yang dicapai oleh suatu perusahaan, dapat diartikan oleh para investor sebagai suatu prospek yang baik bagi perusahaan dimasa yang akan datang. Investor akan berbondong-bondong untuk membeli saham perusahaan tersebut, sehingga harga saham meningkat dan nilai perusahaan akan naik. Semakin tinggi earning powers dari aset perusahaan, artinya semakin efisien perputaran asset yang mengakibatkan semakin tingginya profit margin perusahaan, dan pada akhirnya dapat memberikan manfaat pada semakin meningkatnya nilai perusahaan.

Pengaruh Pengungkapan Corporate Social Responsibility (CSR) terhadap Hubungan Kinerja Keuangan dengan Nilai Perusahaan

Hipotesis 2 membuktikan bahwa CSR mampu memoderasi hubungan kinerja keuangan terhadap nilai perusahaan. Berdasarkan tabel 9 diketahui bahwa variabel Corporate Social Responsibility (CSR) mampu memoderasi hubungan antara kinerja keuangan dengan nilai perusahaan, dengan nilai koefisien regresi positif sebesar 2,759 dan nilai signifikansi sebesar $0,000<$ 0,05 , artinya pengungkapan CSR oleh perusahaan manufaktur dapat memperkuat hubungan kinerja keuangan terhadap nilai perusahaan. Semakin tinggi nilai kinerja keuangan (ROA) dan CSR, maka semakin tinggi juga nilai perusahaan ini terjadi karena CSR juga memiliki pengaruh terhadap perubahan harga saham.

Hasil penelitian ini mendukung teori stakeholder. Menurut teori stakeholder, perusahaan adalah entitas yang menjalankan operasinya bukan hanya untuk kepentingan perusahaan itu sendiri tetapi juga harus memberikan manfaat kepada stakeholder-nya. Semakin tinggi kualitas CSR maka dapat menjamin kelangsungan hidup perusahaan, yang berbias pada keyakinan investor untuk menanamkan modalnya kepada perusahaan (Nahda \& Harjito, 2011). CSR yang diungkapkan dengan baik, akan membuat investor memberikan dukungan penuh kepada perusahaan dalam meningkatkan laba dan kinerja perusahaan.

\section{SIMPULAN}

Hasil pengujian hipotesis 1 menunjukkan bahwa kinerja keuangan yang diproksi dengan ROA terbukti memiliki pengaruh positif dan signifikan terhadap nilai perusahaan (Tobin's Q). Hal ini ditunjukkan dengan nilai koefisisen regresi positif sebesar 0,508 dengan nilai signifkan sebesar 0,000 $<0,05$, artinya kinerja keuangan berbanding lurus dengan nilai perusahaan. Tingkat profitabilitas 
menjadi sinyal yang baik bagi investor terhadap prospek perusahaan di masa mendatang sehingga dapat meningkatkan nilai perusahaan.

Pengungkapan Corporate Social Responsibility (CSR) merupakan variabel moderating terhadap hubungan antara ROA dengan Tobins Q. Hal ini ditunjukkan dengan hasil perhitungan regresi dengan uji Moderated Regression Analysis (MRA) dengan nilai koefisien regresi (standardized coefficients) sebesar 2,795 dan angka signifikansi sebesar 0,000 (lebih kecil dari 0,05). Dengan demikian hipotesis 2 dalam penelitian yang menyatakan "Pengungkapan CSR mempengaruhi hubungan antara kinerja keuangan dengan nilai perusahaan" dapat diterima.

\section{DAFTAR PUSTAKA}

Annisa, I. N., \& Nazar, M. R. (2015). Pengaruh Struktur Kepemilikan Dengan Variabel Kontrol Profitabilitas, Umur, Dan Ukuran Perusahaan Terhadap Luas Pengungkapan Corporate Social Responsibility (Studi Empiris Perusahaan Manufaktur Di Bei Tahun 2011-2013). In e-Proceedings of Management (pp. 313-323). Retrieved from https://libraryeproceeding.telkomuniversity.ac.id/index.php/ management/article/view/1489

Baridwan, Z. (2000). Intermediate Accounting (7th ed.). Yogyakarta: Badan Penerbit Fakultas Ekonomi Universitas Gadjah Mada.

Fachrurrozie, \& Utaminingsih, N. S. (2014). Pengaruh Profitabilitas Terhadap Nilai Perusahaan Dengan Luas Pengungkapan Csr Sebagai Variabel Moderasi. Accounting Analysis Journal, 3(1). Retrieved from https://doi.org/10.15294/aaj.v3i1.3911

Ghozali, I. (2005). Analisis Multivariate dengan program SPSS. Semarang: Badan Penerbit Fakultas Ekonomi Universitas Diponogoro.

Ghozali, I. (2007). Aplikasi Analisis Multivariate Dengan Program SPSS. Semarang: Badan Penerbit Fakultas Ekonomi Universitas Diponogoro.

Hadianto, M. L. (2013). Analisis Pengaruh Kinerja Kenangan Terhadap Nilai Perusahaan Dengan Pengungkapan CSR Dan GCG Sebagai Variabel Pemoderasi (Studi Empiris Pada PerusahaanConsumer Goodsyang Terdaftar di Bursa Efek Indonesia 2008-2011). Fakultas Ekonomika Dan Bisnis Universitas Diponegoro Semarang. Retrieved from http:// eprints.undip.ac.id/42813/1/HADIANTO.pdf

Heriani. (2017). Pengaruh Kinerja Keuangan terhadap Nilai Perusahaan dengan Corporate Social Responsibility sebagai Variabel Moderasi pada Perusahaan Manufaktur di Bursa Efek Indonesia. Universitas Islam Negeri Alauddin Makassar. Retrieved from http://repositori.uinalauddin.ac.id/5803/

http://www.Bursa Efek Indonesia.co.id

Nahda, K., \& Harjito, D. A. (2011). Pengaruh Corporate Social Responsibility terhadap Nilai Perusahaan dengan Corporate Governance sebagai Variabel Moderasi. Jurnal Siasat Bisnis (JSB), 15(1), 1-12. Retrieved from https://journal.uii.ac.id/JSB/article/view/3188

Oktaviani, D. (2013). Pengaruh Kinerja Keuangan Terhadap Nilai Perusahaan Dengan Pengungkapan Corporate Social Responsibility dan Kepemilikan Manajerial Sebagai Variabel Pemoderasi. Fakultas Ekonomi Jurusan Akuntansi Unversitas Gunadarma.

Rahayu, S. (2010). Pengaruh Kinerja Keuangan Terhadap Nilai Perusahaan Dengan Pengungkapan Corporate Social Responsibilitydan Good Corporate Governancesebagai Variabel Pemoderasi (Studi Empiris Pada Perusahaan Manufaktur di Bursa Efek Jakarta). Fakultas Ekonomi Universitas Diponegoro Semarang. Retrieved from http://eprints.undip.ac.id/23232/

Retno, R. D., \& Priantinah, D. (2012). Pengaruh Good Corporate Governance Dan Pengungkapan Corporate Social Responsibility Terhadap Nilai Perusahaan (Studi Empiris Pada Perusahaan Yang Terdaftar Di 
Bursa Efek Indonesia Periode 2007-2010). Nominal: Barometer Riset A kuntansi Dan Manajemen, 1 (2), 84-103. Retrieved from https://doi.org/10.21831/nominal.v1i2.1000

Rustiarini, N. W. (2010). Pengaruh Corporate Governance Pada Hubungan Corporate Social Responsibility Dan Nilai Perusahaan. In Simposium Nasional Akuntansi XIII, Purwokerto (pp. 1-24).

Sugiyono. (2014). Statistika Untuk Penelitian. Bandung: Alfabeta.

Weston, J. F., \& Copeland, T. E. (1995). Manajemen Keuangan. Jakarta: Bina Aksara. Retrieved from http:// lib.ui.ac.id/detail.jsp?id=20131950

World Business Council Suistanable Development dan (PSAK). (1998). Suistanable Development dan (PSAK).

Yuniasih, N. W., \& Wirakusuma, M. G. (2009). Pengaruh Kinerja Keuangan Terhadap Nilai Perusahaan Dengan Pengungkapan Corporate Social Responsibility Dan Good Corporate Governance Sebagai Variabel Pemoderasi. Jurnal Ilmiah Akuntansi Dan Bisnis, 4(1), 1-10. Retrieved from https:// ojs.unud.ac.id/index.php/jiab/article/view/2582 